\title{
Facilitating Technology Transfer in Offsite Construction Between India and the UK: Drivers and Challenges
}

\author{
Mohammed ARIF ${ }^{1,4}$, Aman GUPTA ${ }^{2}$ and Isabela de Oliveira BASTOS ${ }^{3}$ \\ 1. Professor, School of the Built Environment, The University of Salford, UK \\ 2. Assistant Professor, College of Business, Embry-Riddle Aeronautical University, \\ Worldwide, USA \\ 3. Undergraduate Student, School of the Built Environment, The University of Salford, \\ UK \\ 4. Corresponding Author Email: m.arif@salford.ac.uk
}

\begin{abstract}
The increasing demand for affordable housing in developing countries such as India which mainly uses traditional construction technologies begs the need of technologies that are efficient, low cost, and at the same time high quality. Technologies used by developed nations can meet that need if the transfer could be accomplished efficiently. The purpose of this research is to present findings of a survey and follow-up interviews of senior managers from UK and India to explore the drivers and challenges to facilitate technology transfer in offsite construction between the two countries.
\end{abstract}

KEYWORDS:

Technology Transfer, Affordable Housing, Infrastructure Development, Developing Countries

\section{INTRODUCTION}

India is growing at a fast pace, presenting a huge opportunity for its citizens and for the rest of the world. Concomitant with this growth are some challenges. Housing is one such challenge that India needs to address now with a holistic framework that provides sustainable and affordable housing stock. As per the Planning Commission of India, during the Eleventh Plan period, total housing requirement, including backlog, is estimated at 26.53 million units (Planning Commission 2007). Add to this the astounding figure of 42.6 million people consisting of 8.2 million households in 640 towns living in slums (Planning Commission 2007); the magnitude of housing requirement especially in the affordable housing sector is simply mind blowing. An extensive study done by the McKinsey Global Institute entitled "India's Urban Awakening-Building Inclusive Cities, Sustaining Economic growth" reports that "despite the evident and growing need for affordable housing, policy makers have thus far failed to develop a workable model for its provision” (McKinsey Global Institute 2010). For example, the report points out that, Mumbai has built a paltry 6,700 affordable housing units a year over the last 30 years (McKinsey Global Institute 2010). This low production rate will not satisfy the housing need of the poor in India and will only compound the affordable housing problem. A number of government led initiatives have been started over the last decade to solve this crippling problem. Starting with a revised National Housing Policy in 2007; programs such as the Indira Awas Yojna, Rajiv Awas Yojna, and Jawaharlal Nehru National Urban Renewal Mission promise to fulfil the dream of millions of Indian households of home ownership. Citing examples of international experiences such as the Brazil's Minha Casa project, a report developed by the Royal Institution of Chartered Surveyors (RICS) highlights the importance of construction technologies to promote mass 
housing developments at subsidised costs in an environmentally sensitive way (RICS Research 2010).

Given the speed of construction required to meet this huge gap in supply demand it is important that we look at innovative technologies and implementation methods offered by offsite construction techniques. Countries like the UK have been implementing offsite construction since the Second World War, and have experienced different levels of success in the implementation of offsite. Indian construction companies can definitely learn from experiences of their UK counterparts. In order to facilitate transfer of knowledge and eventually transfer of technology between construction companies of the UK and India it is important to look at major drivers and challenges. This paper summarizes some of these drivers and opportunities.

\section{LITERATURE REVIEW}

Implementation of technology in construction sector has seen significant growth in the last decade. There are two mechanisms of acquiring technology, "generation and importation" (Amaratunga et al., 2005). Generation means the development of new technology through the application of knowledge for the production of goods and services (Ofori, 1994), while importation refers to process of obtaining technology from others and development of skills to adapt, operate and manage it (Amaratunga et al., 2005).

Li-Hua (2006) presented the results of a survey on appropriateness and effectiveness of Technology Transfer (TT) and concluded that knowledge transfer and technology transfer should go hand in hand. Without knowledge transfer, effective technology transfer doesn't take place. Li-Hua (2006) also concluded that if there is a big gap between two countries in terms of economic development, technology transfer is not easily achievable. Ofori (1994) discussed internationalization, the barriers of technology transfer between developed and developing countries, and finally ways to overcome those barriers. Ofori (1994) emphasized the need for future studies on internationalization. Whitla et al. (2006) examined the extent of adopting the global strategies by British construction companies using a two-stage case study. The study showed that most firms operating worldwide are not using integrated global strategies effectively. Stewart and Waroonkun (2007) presented a TT performance measurement framework with eight different perspectives. Waroonkun and Stewart (2008) presented a model for international TT with the four factors including, government influence, transferee characteristics, transferor characteristics and relationship building. The analysis concluded that relationship building between transferor and transferee is the main deciding factor for value creation for the host construction sector. Devapriya and Ganesan (2002) used the construction sector subcontracting arrangements in Sri Lanka as a vehicle to analyze the effectiveness of domestic technology transfer. The authors conclude that for internationally managed projects, design and construction systems should facilitate the domestic transfer of technology.

Carrillo (1996) presented the results of survey conducted with consultants and contractors in UK and US to determine the areas of construction technology transfer that provide maximum benefit to local communities, the most effective way of improving technology transfer, the main obstacles experienced and how these obstacles may be overcome. Carrillo concludes that the obligations for transferors for effective TT should be clearly defined. Carrillo (1996) investigated 12 joint ventures between contractors in UK and contractors in developing countries and their technology transfer experiences. One of the major barriers identified by them was lack of incentives to transfer technology. Cushman et al. (1992) discussed the three 
major barriers to TT in US construction industry to be building codes, conservatism, and organizational inertia. Chinese government's strong preference for joint ventures over other means of TT is discussed by Tsang (1995). Tsang also presented issues involved in implementation of TT in Sino-foreign joint ventures. Tsang (1997) grouped the six factors published in previous studies into three categories namely, resource constraints, resource requirements, and resource protection and applied resource-based view to explain a firm's selection of international technology transfer mode.

Given the challenges associated with TT, this paper explores the main challenges between UK and Indian construction organisation in the area of offsite construction. The next section presents the methodology of this paper and is followed by the analysis of results of data analysis.

\section{METHODOLOGY}

In order to understand the main issues surrounding the TT of offsite construction technology between India and the UK, a delegation consisting of 35 senior managers from UK offsite construction sector to India. After hosting two events which facilitated interaction of these managers with their Indian counterparts in New Delhi, a survey was administered. In total there were 151 respondents to the survey. 126 of these respondents were senior managers from Indian construction industry and remaining 35 were the visiting senior managers from the UK. The research team wanted to analyse the differences between the views of UK and Indian managers and therefore independent $t$ test was used to see the differences/similarities in the views of managers from the two countries, in addition follow-up interviews with 4 senior managers were conducted to understand the results of the t-test. Next section presents some of the major findings of the data analysis.

\section{FINDINGS OF DATA ANALYSIS}

After compiling the data and running independent $t$ test to see the similarities and differences between the Indian and UK managers on major challenges facing TT we have obtained the following results. The first issue was regarding closeness of fit of existing UK technology to Indian context. UK managers felt that this is definitely an opportunity for Indian organisations to take advantage of UK offsite construction technology. However, their Indian counterparts disagreed with UK managers. They felt that there is a need to adopt technology to Indian context as most of these technologies cannot be implemented in India without modifications.

Construction in general and housing in particular reflect the local norms, customs and living standards. In this particular case, use of any timber frame or Structural Insulated Panels (SIP) which have gained popularity in the UK are infeasible in India due to a climate that helps termite infestation. This will destroy any structure over few years. On the other hand steel frame technology with sheetrock might also not work due to perceptions of fragility. In India, occupants need to get a feeling of robustness and safety in their house, and anything that is not brick and concrete will not be easily accepted. They will have to consider the culture in Indian construction sector which is quite labor intensive and then modify parts of it to suit Indian context. One Indian manager narrated a story about adopting a concrete based SIP technology. He had sold a rural house to an individual which was made of concrete based SIP. The family moved in and tried to nail the picture of a god on the wall. Since it was SIP and the concrete on both sides was about half an inch thick, the picture did not stick and came down. This led to panic in the family and they came to a decision to abandon the house as in their opinion god did not want to bless the house. This was a cultural issue but maybe the 
product manufacturer should have thought of this step and should have provided provisions for hanging pictures of god(s). However, despite this difference in opinion of how technology should be transferred, managers from both the countries agreed that there is definitely a need to transfer technology and appropriate mechanisms should be investigated further.

Managers from both the countries felt that before transfer of technology there is a need to transfer the knowledge. More interactions between construction professionals from the two countries will help in knowledge transfer. The knowledge transfer is necessary to educate designers, architects and structural engineers and for them to understand how the executing of an offsite project is different from the traditional in-situ construction. It is also important for Indian organisations to conduct more research and development in building materials that could be used more effectively in the Indian context. Materials such as light weight concrete have a definite potential for the Indian market but more research is needed to develop offsite building systems that are suitable for Indian context. Indian road infrastructure makes most of the modular technologies infeasible for most parts of India. If one has to build houses in villages then even the transportation of cranes and other heavy equipment is difficult. So the technology has to be such that it can be assembled manually with any specialised heavy equipment. However, in order to explore this, knowledge transfer has to happen and then appropriate research to adopt the technology will be necessary. Once the knowledge transfer occurs, then it will be easy to facilitate TT. But irrespective of how TT should be facilitated, managers from both the countries did agree that offsite technology definitely provides a viable alternative to meet the large supply and demand gap in India.

UK managers could not understand the challenges faced in importation of technology as the laws governing the importation of technology are not as harsh as Indian laws, so there is definitely a difference in perception of difficulty to facilitate importation of offsite technology into India. This difficulty would require more government to government contact and agreements at high levels. Organisations such as UK Trade and Investments (UKTI) have played an important role in educating UK companies about the hurdles of entering Indian market and the import laws that are in place. One other major dissimilarity between respondents from two countries was the importance of improving labor productivity when using offsite construction. UK managers felt that improvement of productivity is a major driver for the application of offsite construction whereas Indian managers did not feel that they need a mechanism to significantly improve labor productivity as labor is quite inexpensive. Additionally, there is a big housing shortage in rural India, and the housing that is available is unsuitable for the future. However, given the poor road network, specialised equipment could not be transported to rural India and therefore, there is a need to promote technology that could be assembled manually with the need for heavy lifting equipment. This shifts the priorities to the development of technology that is in fact labour intensive.

One of the major issues identified by managers from both the countries was skill shortage in India. The current level of skill shortage and lack of training and education programmes in offsite construction means that there would be a steep learning curve for Indian construction professionals to adopt offsite construction. This will be a major challenge and UK construction sector will have to invest significant amount of time and effort to facilitate TT of offsite construction. However, there are government to government initiatives between the two countries that have helped in interaction of universities and other institutions of learning. These kinds of initiatives will definitely promote development of more educational and training programmes in India that focus on offsite construction. This will further enhance the curriculum and promote the adoption of offsite construction in India. 
There was also a disagreement between Indian and UK managers on the business mechanisms to facilitate TT in offsite. UK managers wanted a franchising model whereas Indian managers preferred Joint Ventures (JV). UK managers did not want to mitigate risks of failure using franchising model whereas Indian managers felt that a JV is needed as significant adoption of technology will be needed to implement UK technology in India. This would require a closer relationship between organisations from the two countries and JV would probably facilitate that better. Most UK construction organisations see TT as just an opportunity to open a new market and new revenue stream for them whereas Indian organisations see this collaboration as a paradigm shift and a major opportunity to exploit unmet demand which will transform Indian construction in the future. Also, since 95\% of construction sector organisations in the UK are Small and Medium Enterprises (SMEs), they are quite risk averse. They don't see long term potential that Indian markets have to offer and therefore insist on franchising model. More needs to be done to make some capital available in the shape of low interest loans and grants which could probably help these UK SMEs work with their India counterparts more closely in order to facilitate the adoption of offsite technology for the Indian context.

The major driver for Indian organisations to adopt technology like offsite is to develop the knowledge in its construction sector about faster and more efficient technologies. However, the major drive for UK managers is profitability. In addition, they see Indian market as a good place to learn about the challenges facing implementation of technology in the developing world and use this learning to expand their business and exports to other developing countries. However, what most UK organisations do not realise is that there is a need for some investment before they can actually start drawing on the knowledge gained from their experience in India. There are several countries in Middle-East and Africa where technologies developed for Indian context could be exported. However, UK organisations need to understand the potential and work to facilitate the adoption of offsite in India. The volume of business that India has to offer is so big that success in India could mean significant profitability and revenues for UK companies.

\section{CONCLUSIONS}

The drivers for UK and Indian managers to facilitate TT are different. For UK managers this TT is an opportunity to open a new revenue stream whereas for Indian managers it is the need to exploit significant unmet demand. Both UK and Indian managers are risk averse when considering TT. UK managers want a franchising mechanism in order to avoid any issues with implementation failure whereas Indian managers want a JV in order to ensure closer knowledge transfer which will lead to a more successful TT. This difference in view of mechanism for TT is definitely a challenge that organisations from both the countries will have to overcome in order to facilitate TT. One other challenge is contextualisation of technology which is again an avenue where organisations from both the countries will have to work together more closely to facilitate TT of offsite construction between the two countries.

\section{ACKNOWLEDGEMENTS}

This research was funded through a British Council grant under the UKIERI initiative grant number UKUTP201100141 


\section{REFERENCES}

Amaratunga, R. D. G., Shanmugam, M., \& Rameezdeen, R., (2005). Transfer of technology in construction: absorption capacity and internalisation. Fifth International Postgraduate Conference in the Built and Human Environment, 628-636.

Carrillo, P. (1996), Technology transfer on joint venture projects in developing countries. Construction Management and Economics, 14, 45-54.

Chatterji, M., (1990), Technology Transfer in the Developing Countries, Macmillan, London.

Coolidge, F. L., (2008), Statistics: A Gentle Introduction (2nded.). California, Sage

Publications Ltd.

Cushman, N., Nam, C., and Tatum, C., (1992), Technology Transfer in Building Construction

-Case of Seismic Design, Journal of Construction Engineering and Management, 118(1), 129-141

Devapriya, K. A. K. \& Ganesan, S., (2002), Technology transfer through subcontracting in developing countries. Building Research \& Information, 30(3), 171-182.

Li-Hua, R. (2006), Examining the appropriateness and effectiveness of technology transfer in China. Journal of Technology Management in China, 1(2), 208-223.

McKinsey Global Institute (2010), “India’s Urban Awakening-Building Inclusive Cities, Sustaining Economic growth”, April 2010.

Ofori, G., (1994), Construction industry development: role of technology transfer Construction Management and Economics, 12, 379-392.

Planning Commission (2007), “Eleventh Five Year Plan 2007-12 Volume III: Agriculture, Rural Development, Industry, Services and Physical Infrastructure”, Planning Commission, Government of India.

RICS Research (2010) “Making Affordable Housing Work in India”, November 2010

Stewart, R. A., \& Waroonkun, T. (2007), Benchmarking construction technology transfer in Thailand. Construction Innovation, 7(3), 218-239.

Tsang, E.W.K. (1995), The implementation of technology transfer in Sino-foreign joint ventures, International Journal of Technology Management, 10 (7/8), 757-766.

Tsang, E.W.K. (1997), Choice of international technology transfer mode: a resource-based view, Management International Review, 37, 151-168.

Waroonkun, T., \& Stewart, R. A. (2008). Pathways to enhanced value creation from the international technology transfer process in Thai construction projects, Construction Innovation, 8(4), 299-317.

Whitla, P., Walters, P. \& Davies, H. (2006), The use of global strategies by British construction firms. Construction Management and Economics, 24(9), 945-954. 